\author{
LARISSA Titarenko \\ BELARUSIAN STATE UNIVERSITY \\ E-MAIL: LARISSA@BSU.BY
}

\title{
INTER-CIVILIZATIONAL ENCOUNTER: PLURALISTIC DISCOURSES IN THE REPUBLIC OF BELARUS
}

\section{Introduction}

The Republic of Belarus is a new nation-state that appeared on the ruins of the Soviet Union in 1991. It is a relatively poor country with more than 95\% dependency on Russian energy. It is situated between the European Union on the West and Russia on the East. This geopolitical position can be interpreted within the theory of clashes of civilization developed by S. Huntington [1996] as a borderland between two different civilizations, Western and Orthodox. As Huntington predicted, all eight religion-based global civilizations are in constant conflict with each other. Regardless of this theory, Belarus is a country that borders upon the two modern geopolitical powers, the European Union and Russia, and has to deal with both of them. Additionally, in the south Belarus borders Ukraine: after the Maidan revolution (2014) it is a new challenge that stimulates attempts by the Belarusian government to avoid any political and cultural revolt within the country, i.e. from revolution. Due to these attempts and balanced policy, there are no significant political conflicts or cultural (religious, linguistic) contradictions in contemporary Belarus (at least, any potential conflicts are under state control). There is a balance even in Belarusian foreign policy: being in close cooperation with Russia as a member of the Eurasian Economic Union, Belarus supports a friendly relationship with Ukraine and stays neutral in the political and economic clashes between Russia and Ukraine. More than that: Belarus tries to arrange peaceful negotiations between the opposing parties within Ukraine so that they can create a platform for peaceful diplomatic settlement of their problems in the Donetsk region. 
This political tolerance to different countries and desire to negotiate with all of them - whether they are huge regional players (like the European Union and Russia) or regional states (like Ukraine) - demonstrates that the official line of contemporary Belarusian policy is really oriented to mutual respect, diplomatic compromise, and pragmatism in its relations with any political entity. The possible reasons for such a tolerant policy is not only the political good will of the Belarusian president, but a broad understanding that the Republic of Belarus is too small and weak to play any independent role on the global and regional political arena. Therefore, the most pragmatic position is to be in good relationships with all its neighbours, stay politically neutral in their conflicts, and pursue its own political and economic interests. Indeed, Belarus demonstrates a neutral attitude toward quite different political regimes in the sphere of international relations.

This political pluralism of the Belarusian state became visible when the country decided to overcome its previous political isolation and improve its position on the global arena: some political changes were made within the country and even more positive steps have been made in its relationship with the EU and the US. The recent political reputation of Belarus has been improved: now it has the image of a tolerant and reliable country in Eastern Europe, even as a last piece of stability in the center of this region.

As for everyday social life in Belarus, it differs from two other postsoviet borderland countries. Unlike Russia, there is no actual threat of terrorism or ethnic problems. Unlike Ukraine, there is no strong political confrontation between the leftist and right parties, or between regional oligarchs, for power. Belarus can be viewed as a rather conservative (or traditional) society, however, it is really a calm land on the border between East and West. The state does not have any political and territorial demands on other states, and all the people regardless of race, ethnicity, religious beliefs, or gender, are equal as citizens of Belarus.

Belarus can be considered as a multicultural society in the sense that multiculturalism means the joint social activity of different ethnic groups and nationalities that have been living on the territory of contemporary Belarus for centuries. This type of multiculturalism is not similar to the western type that relates to the relationship between the residents of Western states and different migrants coming from Africa, Asia, and other poor regions. Therefore, the people of Belarus have adjusted themselves to the pluralist life side by side to each other since a long time ago; they view Belarus as their "common house". Regardless of the fact that the Belarusian nation is the titular one, all other ethnic groups do not consider themselves 
as migrants or minorities or foreigners: they are all equal citizens of Belarus, respect all ethnic groups and share the existing multi-ethnic pluralistic culture [Kharitonov 2012: 187].

This interpretation of multiculturalism relates primarily to cultural phenomena (religious and ethnic pluralism, multiplicity of identities, etc.). The multicultural practice embodied in multilingualism allowed the people of Belarus to reduce the tensions among the population in the mid-1990s when a Russian received equal status with a Belarusian and gave all the social groups of the population the chance for peaceful post-soviet transformation of the country toward a stable, socially oriented state.

The paper describes the processes of peaceful ethnic relationship in Belarus, explains the existence of religious tolerance among the people, and their cultural pluralism. As for political discourse, the author shows the objective reasons for the neutral attitude of Belarus to different political regimes in the sphere of international relations.

\section{Phenomenon of tolerance in Belarus}

First, it is necessary to explain the meaning of the terms that are used in this article. As usual, it is easy to find different interpretations and understanding of such concepts as tolerance, multiculturalism, or pluralism in contemporary public discourse and scientific literature, especially between authors from different countries and political outlooks.

In the Western context tolerance can be explained as a positive or neutral attitude toward diverse people regardless of their political views, religious beliefs, sexual orientations, ways of life, world outlooks, traditions, as well as race, gender, age, etc. For example, J. S. Mill defended religious tolerance as a part of his liberal outlook [1985]. American sociologists G. H. Mead [1934] and H. Blumer [1965] wrote in favor of racial tolerance in regard to their theory of the group. Tolerance also can be understood as respect to any other views, behavior, ways of self-realization, and types of individuality. In short, it can be defined as respect for any other different culture and its acceptance as equal to one's own culture, including religion, traditions, practices, or way of life [Webster's 2014]. In contemporary political context tolerance is viewed as a part of the European values in the Treaty of Lisbon and other official documents of the EU.

Tolerance is the basis of interpersonal communication and the very existence of human beings. From this view, tolerance means an efficiency to accept the "Otherness" of different people and nations in the culture, way of 
life, traditions, behavior, and readiness for dialogue with other people living in the country, even if they differ significantly. In other words, tolerance in the multicultural environment is a necessary feature of life, a practical embodiment of the philosophy of equality of people in a multicultural society.

At the same time, many western authors have expressed their negative attitude toward tolerance, especially in cases of unlimited and unconditional acceptance of so called "others" (such as foreigners, representatives of different religions, etc.) and their behavior. Thus, H. Marcuse insisted that the pure tolerance that permits any behavior and any ideas may lead to totalitarianism and therefore deserves "repressive intolerance" against it [1965]. He claimed that tolerance has to be based on rationale and truth. In particular cases cultural tolerance can bring about violence against the majority (for example, the terrorist attacks on a religious basis in France in 2015) or to the infringement of interests of the population in the recipient countries in the case of unlimited illegal migration (like in several EU countries in 2015).

In Russia the same actions brought about even more strong opposition toward unlimited tolerance; sometimes unlimited tolerance is viewed as a universal European value and practice and therefore it is connected in the Russian mentality with contemporary problems of migrants and terrorism. For many Russian believers, tolerance of homosexuality is not acceptable as well as tolerance of migrants who do not want to adapt themselves to the cultural norms of the receiving society and follow its norms [see for example: Ivankina 2015]. Intolerant views are often expressed in the media against migrants, Muslims (as potential terrorists), people of any religion beyond Russian Orthodoxy, and the like [Xenophobia 2015]. According to this approach, western multiculturalism as a policy has failed [Kharitonov 2012].

\section{Ethnic tolerance}

Tolerance as a characteristic of Belarusian mentality belongs to all ethnic groups that inhabit Belarus: Belarusians, Russians, Poles, Tatars and representatives of many other small ethnic groups united by the category "citizens of Belarus". According to the latest survey, the Republic of Belarus is a multi-ethnic state where $84 \%$ are Belarusians, $8 \%$ are Russians, $3 \%$ - Poles, $2 \%$ - Ukrainians. Smaller groups include Jews, Armenians, 
Georgians, Gypsy, Tatars, Azeri, Lithuanians. Overall, there are around 140 ethnic groups whose representatives live in the Republic of Belarus [Itogi perepisi, 2010].

The phenomenon of ethnic tolerance is common for Belarusian public discourse and for Belarusian media. Sociological data also support this statement. Thus, the Institute of Sociology ran a national survey in 2013 with the goal of finding whether respondents could easily accept individuals who differ from them by ethnic background as members of their own family, as neighbours, colleagues, tourists, or citizens of Belarus. The attitudes of respondents towards people of other ethnicities were measured by the Bogardus scale of social distance. This procedure is known as the Bogardus test on ethnic tolerance. The social distance was considered as minimum in cases when a majority of respondents were ready to accept representatives of other ethnicities as family members, or neighbours, or colleagues. In the opposite cases the social distance was interpreted as important and large. If index is equal to 1 (maximum), then respondents view other people as absolutely equal and similar to themselves (i.e. very close to themselves).

On the basis of several questions sociologists constructed indices of social closeness for each ethnic group. As this survey demonstrated, Belarusians feel themselves most close to other Slavic nations: Russians (0.90), Ukrainians (0.85), and Poles (0.78). Representatives of these nations live in contemporary Belarus and therefore it is common for ethnic Belarusians to communicate with them on an everyday basis [Sosnovskaya 2014: 616]. Moderate social distance is typical in regard to the Baltic nations (0.72) and western Europeans (on average 0.73 ). At the same time Belarusians seem to be less tolerant toward nations that are not common in this region: Africans (0.50), Chinese (0.51).

This survey found that the age and education of the respondents influence the results (the level of tolerance to others): on the one hand, young people are more tolerant to other ethnic groups (including Africans, Americans, Chinese, etc.) than older people; on the other, the most educated groups are much more tolerant toward all ethnic groups than people with a low level of education. However, positive attitudes toward the representatives of ethnic groups that traditionally live in Belarus do not depend on age, education, or region (urban or rural, south or north). These data prove the fact that young citizens of Belarus born after 1991 have been socialized in a more democratic and open society than their parents and grandparents. 
The data of this survey confirm that the social-economic situation of a country and economic level of an individual are significant criteria of their opinions and values. According to the results, people whose income was below the average by their self-evaluation (28\% of respondents) demonstrated a higher level of ethnic tolerance than people with the middle level of income (more than 57\% in this survey) and high income (around 7\%). For example, people with high income are less tolerant toward Gypsies, Jews, and people from the Caucasus than those people that identified themselves as poor (or below the average). These results are not typical for neighboring countries. Therefore, from our approach, the level of tolerance cannot be viewed as an inherent characteristic of the behavior or mentality of Belarusians; tolerance is a result of the specially oriented state policy towards the equality of all people, a product of public efforts to construct a peaceful place of living for all. Also, tolerance is a result of historic conditions under which different ethnic groups co-existed in this territory for a long time. As a result, the image of Belarus as a tolerant state is typical for citizens of Belarus themselves [Sosnovskaya 2013].

Recently in 2015, a small survey devoted to trust and tolerance among young people was made by the author in a Belarusian state university. The results demonstrated that the younger generation of Belarusians almost equally evaluate people of different ethnic and religious backgrounds. The most significant criteria to differentiate people is employment: the students trust and respect people that have a job on a higher level than those without a job. Overall, this survey revealed that modern students are indifferent to national-ethnic-religious differences: no preferences of this kind were expressed. It means that social criteria are most important if it is necessary to decide whom they would trust and whom they would prefer to communicate with.

\section{Pluralism of Religions and Mixture of Religious Beliefs}

Religious tolerance in this article is viewed as a positive value that means that people belonging to different regions live in peace and respect to each other's beliefs and traditions as acceptable in a diverse society. The background of this positive attitude towards religious tolerance is the interethnic and interreligious tolerance in contemporary Belarusian society: there are no significant conflicts between the people belonging to different religions. 
Belarusians do not have a reputation of strong believers like Poles: almost half of them do not consider themselves as religious believers, according to sociological data [Novikova 2007]. Additionally, they do not care much about the religious beliefs of people around them.

Religious pluralism can be approached from different angles, where the variety of Churches and the diversity of religious beliefs seem to be most relevant. In contemporary Belarus one can find both aspects of religious pluralism (Churches and beliefs), though in different proportions which depend, among other things, on the historical past of Belarus and the current relationship between religion and state.

According to data from the European Value Studies (EVS), in the beginning of the current century more than half of the respondents belonged to a religious denomination [Halman 2001: 74].

Although the majority of believers are Orthodox, they are not, in fact, very strictly observant. According to Pollack and Muller, only $37 \%$ of those who said they belonged to a religious denomination or Church in Russia, confirmed their actual Church membership [Pollack, Muller, 2006: 24]. As for the Roman Catholic Church, this religious institution seems to be more demanding of its believers. As a result, Roman Catholics in Belarus declare their affiliation more actively than Orthodox believers do.

The whole religious picture of Belarus includes many more varieties of religious beliefs. Like elsewhere in Europe, one can find here traditional religions as well as many new religious movements. Thus, as of 01.01.2009, the number of registered religious confessions had reached 25. Current religious communities, registered in the Ministry of Justice of Belarus, include both traditional and new religious denominations and movements. In 2002, there were 89 new religious movements of Oriental (Krishnaites), Christian ('Church of Christ'), mystical (School of Arkans), nontraditional Christian (Mormons), and other orientations; in 2009 - almost a hundred.

At the same time, many people do not identify themselves as religious at all, even though the number of atheists has decreased greatly in comparison with the previous (Soviet) period. For example, in the mid-1980s, according to some estimates, $40 \%$ of the people were atheists, and only $22 \%$ believers; in 2003 this ratio had changed in favor of religion: $11 \%$ were atheists and 50\% believers [Beznyuk 2003: 157].

Religious pluralism becomes apparent in the plurality of beliefs. Theoretically, those who identify themselves as believers would be expected 
to know the basic dogmas of their religion (although this may differ in degree depending on the religion). In practice, this is not the case in Belarus. The EVS survey (1999-2000) data discovered that only 4\% of respondents who indicated themselves as believers did not select any non-Christian beliefs. From the traditional Orthodox view, only those $4 \%$ could be considered as 'truly Orthodox believers'. At the same time, more than a quarter of respondents believed in both traditional and non-traditional things while even more (28\%) had no such (traditional or non-traditional) beliefs at all.

One can interpret the variety of types of contemporary religiosity as a manifestation of religious pluralism within the same Orthodox confession. From this point of view, a new type of religiosity connected to the Orthodox Church (where the believer may have some mixed religious beliefs), exists together with the traditional type of religiosity (where the believer is an individual who belongs to the Church, fully supports 'true Orthodox beliefs', and regularly attends religious services) and some other intermediate types constructed in the modern sociology of religion.

On this basis one can assume that the type of believer described as 'believing without belonging' [Davie 2000] has become an essential part of the Belarusian religious situation. The new type of religiosity (a believer without Church affiliation) has become typical for contemporary Belarus even on a higher level that the traditional type of religiosity associated with institutions, dogmas, and particular kinds of religious practices. Usually, individuals with this type of religiosity combine Christian and non-Christian beliefs. They also identify themselves as Christians, even though their new, popular type of religiosity differs greatly from the purified religion described by theologians (the so-called 'traditional' type).

In order to distinguish between the different religious beliefs, several types of consciousness have been constructed on the basis of sociological data. Thus, Lidia Novikova named four types [2007: 48]: religious (associated with any religious beliefs), quasi-religious (associated with belief in transcendental forces), searching (focused on uncertainty and fluctuation of beliefs), and non-religious (without any beliefs of a religious kind). Novikova explained the existence of this plurality of religious beliefs and types of religious consciousness by the lack of traditional religious knowledge in post-Soviet people and their need for a new world outlook that would replace the previous one. According to her, the new types of 
consciousness dominate over the traditional religious type that prevailed in the pre-revolutionary, pre-Soviet Russian empire. All the new types are connected with religious views; however, they are usually eclectic and vague in their nature [Novikova 2007: 49].

The relationship between religion as a social institution and the Belarusian state has contributed greatly to the process of constructing a tolerant atmosphere for all confessions and respect between different believers. On the one hand, post-Soviet Belarus is a state where state authorities are separated from the religious institutions. This model of relationship between the state and the Churches is defined in the constitution of Belarus; it demonstrates the continuity of state policy towards religion from Soviet times. On the other hand, the Belarusian state tries to regulate and even strongly control public life in general. For this reason, the state needs mechanisms to connect them with all the institutions of society. The social contract with the Churches in Belarus plays the role of social regulator between these important institutions.

According to the Law on Freedom of Conscience, four traditional religions have been identified: Orthodoxy, Roman Catholicism, Judaism, and Islam.

The fact is that during the post-Soviet period public trust in the Church generally increased while public trust in political institutions declined. Therefore, the contemporary post-Soviet state seeks to use religious potential and religious prestige for its own purposes, primarily for increasing its own power and consolidating society around the idea of dominant religious values. In order to fulfill successfully this basic need, the post-Soviet states have signed special agreements with the most important Churches in their countries. In Belarus, such agreements were signed. According to the new edition of the Law 'On Freedom of Conscience and Religious Organisations' (November 2002), the 'dominant role of the Orthodox Church in the formation and development of the spiritual, cultural and state traditions of Belarusians' was confirmed. Recently, when the Roman Catholic Church also expressed a desire to sign a similar agreement, work on this has now started. It is expected that such an agreement can be concluded soon. As for the other traditional Churches, they are relatively smaller, so, as officials explain, there is no practical need for such agreements: they also can work in different spheres of society as long as they are within the law [Kotlyarov, Zemlyakov 2004]. 


\section{Religious Plurality and the State in Belarus}

In general, the religious situation in Belarus can be characterized by the following important features: pluralism of religious organisations, free choice of religious beliefs by the individual, special agreements between two of the Christian Churches and the state, and religious tolerance among the population.

According to some data, more than half of the population in Belarus consider themselves to be religious, as they embrace the idea of God. Among them, more than $75 \%$ are Orthodox; around $10 \%$ are Roman Catholics, while the rest belong to other Churches and sects [Halman 2001]. As for the number of religious communities, their proportion, according to the statistics, is the following: Orthodox $-45 \%$, Catholic - 15\%, Protestant $-32 \%$, and others $-8 \%$ [Kotlyarov, Zemlyakov 2004: 126]. According to some research estimates, there are around 400 new religious movements in Belarus; approximately half of them have come from abroad while the other half have local roots [Martinovich 2008]. This fact - the variety of new religious movements along with the diversity of major religious denominations - supports the statement that the religious situation in Belarus resembles a mosaic where many Churches, sects, and movements co-exist. This is also proof of the individualisation of religious beliefs in Belarus.

What is the official attitude of the state toward this pluralism?

The agreement between the state and the Orthodox Church signed in 2003 provided this Church with some privileges in practical life: the Orthodox Church obtained access to the army, hospitals, schools, and other institutions. However, current relations between the state and the Roman Catholic Church have improved greatly as well. Since 2008, some important official visits between the Vatican and Belarus have taken place. In the spring of 2009, Belarusian president Lukashenko visited the Pope in the Vatican and discussed with him the religious situation in Belarus and other post-Soviet states. This visit was aimed at demonstrating that Belarusian authorities treat equally the two Christian Churches that have the status of traditional ones and are supported by the majority of believers. A special agreement between the government and the Catholic Church - similar to the one between the Orthodox Church and the state - is to be signed, so that both Churches will enjoy similar access to public institutions in Belarus. In the case of Belarus, such an agreement can be viewed as a legal basis allowing for increasing religious pluralism, since it would provide 
the Roman Catholic Church opportunities similar to those the Orthodox Church enjoys.

As for other religious denominations, people are allowed openly to support them - as long as these organisations function within the legal basis provided by the law. It should be noted that the state considers certain sects and cults dangerous for the population, and their activities are strongly restricted by the state, while many new religious movements are banned outright [Kotlyarov, Zemlyakov 2004: 148-149]. For example, the Hare Krishna community in Minsk was forced out of its office in December 2006 because in November 2006 the authorities denied it registration for some formal reasons. Therefore, it is difficult to estimate precisely how many people support new religious movements in Belarus. However, the very fact of their existence confirms the religious pluralism in the country.

Another important feature of the religious relations in Belarus is tolerance between the different religious organisations. Usually, such organizations show no hostility toward each other even when competing for new believers. No major religious conflicts or religious splits (similar to those in Ukraine or Russia) are to be expected in Belarus. In the opinion of the ex-leader of the Belarusian Orthodox Church, Metropolitan Filaret, the reasons for such splits and conflicts in the post-Soviet space are usually political: 'It is obvious that the historical heirs of the major world religions - Judaism, Islam, and Christianity - are fighting with each other. However, the reason for these conflicts is in the heirs themselves and not in the religious legacy' [Metropolitan Filaret 2006: 66]. Being aware of possible battles on religious grounds, the Belarusian Orthodox Church seems to be doing its best to avoid conflicts with other Churches and religious organisations. The role of the Orthodox Church in maintaining religious peace is very important, as is the personality of its current leader.

One can add some important historical references related to religious tolerance. Historically, the territory of Belarus was a motherland for a different kind of believer. The ethnic composition of the population of the Grand Duchy of Lithuania (a state of which today's Belarus was a part for several centuries), and then the Northern-Western Kray of the Russian Empire (in the $19^{\text {th }}$ century) was always diverse. This fact contributed to the mosaic religiosity: people of different beliefs had to live in the same villages and cities, depend on each other, and therefore be tolerant. Before the October revolution, cities were mostly Jewish: for example, in pre1917 Minsk the number of synagogues was higher than the number of all 
Christian Churches taken together [Titarenko 2007]. Accordingly, there were more Judaist believers than Christian ones; and only the state policy of Russian empire with its principle "Divide and rule" generated religious and ethnic conflicts between them. After the revolution, the multi-ethnic population suffered from the Soviet policy toward religion and secret police repression, then from the Nazi occupation, but not from inter-religious conflicts. Overall, this historical heritage of peaceful coexistence helps the current population in Belarus peacefully live in a multicultural pluralistic (partly religious, partly non-religious) society.

This statement can be illustrated by the following fact. After 1991, two synagogues were quickly restored in Minsk. On the one hand, this is not much. However, as the number of Jews is small, Minsk municipal authorities do not consider new synagogues as a primary need for the Jewish community. On the other hand, post-Communist Belarus demonstrates religious plurality: all the so-called traditional denominations are officially supported because of their 'contribution to the spiritual life of the population of the country'. The existing variety of believers and nonbelievers confirms the fact that contemporary Belarus enjoys a high level of religious plurality.

The important factor that contributes to insuring religious balance is the state itself: state regulations on relations between religious and non-religious organisations contribute to the tolerant situation in Belarus. This fact is recognised by scholars as well as by the representatives of different confessions in Belarus. It does not necessarily mean that there are no conflicts between the believers or the Churches; however, when they arise, they are peacefully resolved.

Sociological surveys run by the Institute of Sociology also confirm that relations between the believers of the main religious confessions are mostly peaceful. According to Novikova [2007: 48], the level of tolerance consistently grew between 1998 and 2006 in all selected groups of different consciousness (religious, quasi-religious, hesitating, and non-religious). Thus, among religious persons the level of tolerance increased from $58 \%$ to $76 \%$, among the group of the quasi-religious - from $49 \%$ to $76 \%$, among the seekers (hesitating) - from $64 \%$ to $83 \%$, and among non-religious persons - from $68 \%$ to $84 \%$.

In 2008, a public organisation called 'Dialogue Eurasia' was established in Belarus with the mission to promote a peaceful intercultural dialogue between Christianity and moderate Islam (the organization embraced some former Soviet countries and Turkey). This initiative was supported by the 
state, business, and the public: joint conferences of representatives of these religions regularly take place, public discussions and scientific meetings are organized, exhibitions are open, and books are published. This is also evidence that Belarus is a place of peaceful coexistence of many religions.

\section{Conclusion}

Regardless of some political stereotypes and negative attitudes about the political regime in the Republic of Belarus, this country demonstrates to the borderland region and Europe as a whole its multicultural nature and pluralism in several social and cultural spheres of life. Citizens of Belarus of different ethnic and religious background peacefully coexist and have equal rights according to the Constitution.

Belarus does not fit the framework of a democratic and liberal state in western terms. Still, it is a place where the population live without social, class, ethnic or cultural clashes, and enjoy social stability.

\section{Bibliography}

Beznyuk D.K. (2003), Osnovy Sotsiologii Religii, Minsk.

Blumer H. (1965), "Industrialization and Race Relations", Hunter G., ed. Industrialization and Race Relations, 220-253, London.

Davie G. (2000), Religion in Modern Europe, A Memory Mutates, Oxford.

Halman L. (2001), The European Values Study: A Third Wave, Tilburg. Huntington S. (1996) The Clash of Civilizations? The Debat, NewYork.

Ivankina G. (2015), Krovavo-tuhly zakat [Blood-rotten sunset]. Electronic resource. http:// zavtra.ru/content/view/krovavo-tuhlyij-zakat, Access: 26.11.2015.

Itogi Perepisi: natsional'ny sostav ziteley Belarusi (2010), http://naviny.by/rubrics/society/ 2010/11/02, Access: 02.11.2010.

Kharitonov I. N. (2012), Krisis politiki multikulturalizma I zenophobija v stranah Evropy, "Sotsiologicheskij Almanac", nr 3: 186-195, Minsk.

Kotlyarov I.V. \& Zemlyakov Y.L. (2004), Respublika Belarus v konfessionalnom izmerenii, Minsk:

Novikova L.G. (2007), Adaptatsija naselenija $k$ uslovijam zhizni $v$ nestabilnom obshestve i religioznost, "Sotsiologia", nr 2: 46-55, Minsk.

Martinovich V.A. (2008), Vvedenie v ponjatiyniy apparat sektovedenija, Minsk.

Mead G.H. (1934), Mind, Self and Society, Chicago.

Mill J.S.(1985), On Liberty, ed. by G. Himmelfarb. London. 
Metropolitan Minskiy I Sluckiy Filaret (2006), 'Svoboda Veroispovedanija I Priznanie Predstaviteley Drugih Religiy', Minskie Eparhialnie Vedomosti 4: 66-67.

Pollack D., Muller O. (2006), Religiousness in Central and Eastern Europe: Towards Individualisation?, I. Borowik (ed.), Religions, Churches and Religiosity in Post-Communist Europe, 22: 36, Krakow.

Sosnovskaya N.A. (2013), Predstavleniya ob obraze sovremennoj Belarusi v obschestvennom soznanii naselenija strany, "Sotsiologicheskii Almanac", nr 4: 241-247, Minsk

Sosnovskaya N.A. (2014), Ethnicheskaya tolerantnost' naselenija Belarusi. Sotsiologicheskiy analys, 9-e Kovalevskie Chtenija, 616-618, S.-Peterburg, http://soc.spbu.ru/nauka/ publications/k9_4r.pdf. Access 10.11.2015.

Titarenko L.G. (2007), Construction/Reconstruction of a City's Identity: The Case of Minsk, A.Vosyliute (ed.), Social Groups: their Past and Present, 272: 288, Vilnius.

Webster's New World College Dictionary (2014). Fifth edition. Springfield, MA.

Wolff R.P., Moore B., and H. Marcuse (1965), A Critique of Pure Tolerance, London.

Xenophobia sosredotachivaetsja: interview s Vladimirom Mukomelem (2015), "Vestnik Obschestvennogo Mnenija”, nr 1: 130-140, Moskwa.

\section{SUMMARY}

\section{Inter-Civilizational Encounter: Pluralistic Discourses in the Republic of Belarus}

There is a stereotype that the Republic of Belarus is a country where pluralism does not exist in all spheres of life. However, this statement is not precisely correct, as contemporary Belarus demonstrates political neutrality and pluralism in the foreign policy and multiculturalism inside the country. Multiculturalism is viewed in the paper as mutual tolerance among the population and respect to the Otherness in cultural life. Two major spheres of pluralistic phenomenon are discussed: ethnic composition of Belarus and its religious confessions. Although a major part of the believers belongs to two Christian confessions, Orthodox and Catholic, many other confessions and new religious movements also exist. Religious pluralism is a practical reality in Belarus which has the reputation of the most religiously tolerant post-Soviet country. Contemporary laws provide the legal basis for tolerant relations in the country, and there is a historical tradition of religious tolerance in Belarus.

KEYWORDS: multiculturalism, political pluralism, religious and ethnic tolerance, borderland, Belarus 